\title{
Research on Dedicated Primary School bus Equipment Performance and Safety Standards Based Technology
}

\author{
Songlin Zou \\ Jiangxi University of Technology, Nanchang 330098, China
}

Keywords: Safety requirements and standards; PHEV; ADVISORE secondary development

\begin{abstract}
China's auto industry management focus has shifted to the fields of relationship security, environmental protection, energy, security and other personal safety and health; to mandatory standards formulated by the state-oriented implementation of strict market access system. On the basis of the relevant standards and regulations and management systems study on the school bus to Nanchang six children ages 13 years of age for the target research dedicated primary school bus safety and technical conditions. The main contents include vehicle structure, rollover protection, passenger seat, warning signs, safety belts technical requirements and test methods for equipment and interior materials such as centralized control, establish safety standards and performance standards and hybrid sound of new energy vehicles, school buses research.
\end{abstract}

\section{Introduction}

Children are the future of the motherland flowers society. With the size of cities and rural areas and gradually expand and accelerate the process of school, more and more students take a variety of different, non-dedicated vehicles to and from school or kindergarten, but neither of these temporary school bus body type to meet the physical and psychological characteristics of students also not included in the regular school bus management, can not guarantee the safety of children traveling to and from school.

With the increasing globalization of the auto industry tends to be more fierce competition in the international market standards as the core competitiveness of the basic technology has become an important element of international competition means car, possession of intellectual property and competitive standards have become a measure of core competitiveness an important symbol of power.

\section{Automotive standard system overview and new energy vehicles hair}

Foreign. the world's automotive technical regulations and standards system has a lot, and now automotive regulations and standards in most countries of the world are formulated with reference to Europe or the United States legal system. Europe --- United Nations Economic Commission for Europe to "About wheeled vehicles, equipment and parts for installation or wheeled vehicles using uniform technical regulations and the conditions for reciprocal recognition of approval made under these provisions of the Agreement," "About as wheeled vehicles, can be installed and / or used equipment and parts wheeled vehicles to develop global technical regulations Agreement "and" On the use of regular technical inspections of wheeled vehicles and the reciprocal recognition uniform 
conditions of this agreement check " 3 book a multilateral framework agreement legally binding basis. Authorized by the US federal government department in charge of vehicle safety, environmental protection, energy security and the development of automotive technical regulations, and in accordance with technical regulations on automobile automotive products implementing legal management system. US automotive technical regulations system mainly by the Federal Motor Vehicle Safety Standard (FMVSS) and Federal Motor environmental regulations (EPA), as well as federal energy regulations and federal regulations motor vehicle theft of motor vehicle components. The Japanese government in the form of decrees, departmental order, notice, notice promulgated a series of technical regulations, including eight parts, namely Japan's "Road Vehicles Law" and other relevant laws and regulations to implement; Japan's "reasonable consumption of energy" and related implementation of laws and rules; automotive safety, environmental technical regulations; type certification testing procedures; rules relating to the type-approval tests; bulletin on road vehicle safety regulations; relevant technical standards and safety regulations for road vehicles; vehicle structure standards.

Domestic. China's automotive technical regulations and standards including the notice issued by the relevant government ministries, documents and all levels of standard components, technical regulations currently enforced in the country including the Ministry of Industry and Information Technology, Ministry of Public Security, the National Environment protection Department, Ministry of Transport, the National Certification and Accreditation Administration of the a utomotive industry and other centralized management of the implementation of the relevant ministries issued bulletins and documents, as well as the State administration of Quality Supervision, Inspection and Quarantine, the State standardization Administration of mandatory standards promulgated two levels . Ministry of Environmental Protection also issued relevant regulations and standards related to energy saving cars. Notice documents and vehicle management department of the national mandatory standards issued jointly constitute our car regulations.

Currently, the implementation of mandatory certification of automotive products, including new product announcements, CCC compulsory certification and environmental directory announcement, since these two categories of certification related to market access and product legally sold, they were included in the mandatory certification standards (mainly national compulsory standards, including national voluntary standards, and even the industry standard) is a better-executed.

Domestic energy saving school bus. CNG school bus:

CNG (Compressed Natural Gas) vehicles refers to compressed natural gas as an alternative to conventional gasoline or diesel motor fuel vehicles. At present, domestic natural gas pipeline network conditions, the development of $\mathrm{CNG}$ vehicles are the main areas.

$\mathrm{CNG}$ vehicles refers to the inner cylinder by a gas mainly composed of methane at a pressure of about $25 \mathrm{Mpa}$ in the car is similar to the storage tank for use as motor fuel. The main process in the $0.3 \sim 0.8 \mathrm{Mpa} \mathrm{CNG}$ bus low pressure natural gas, natural gas compressors boost through to $25 \mathrm{Mpa}$, by order of the control panel control, according to high, medium and low pressure gas cylinders stored in the order of the group, and then by the CNG filling machine fill the car cylinders. The high-pressure gas cylinders car then after decompression device decompression gas mixture to the engine via the air supply.

Methanol school bus: 
Methanol is used as the main fuel for cars, but also to gasoline or gasoline - methanol mixed fuel for fuel, a methanol - gasoline fuel flexible conversion of new vehicles with energy saving technology content to be converted from ordinary cars together.

Hybrid school bus:

High fuel economy of hybrid vehicles, and superior driving performance, hybrid car engine to use oil, but at the start, acceleration, because the electric motor assist, so it can reduce fuel consumption, simply put, is the same size compared to lower vehicle fuel costs

\section{Special primary school bus safety and technical standards}

Parking signaling devices FMVSS 131 "school safety device dealers who" provides the school bus must request and with the provisions of two red lights on the device. Use of the device in reducing possible after school bus hit a pedestrian near the vehicle caused by the possibility of personal injury and death. Open the stop signal device when the school bus is ready to stop the site or on the roadside, with a school bus in front of and behind the vehicle in both directions after seeing this device is open, you should immediately slow down and keep school bus stop within a predetermined distance, not near by this guaranteed the safety of children on and off.

Transverse control arm kids went to the front of the driver to avoid invisible blind, is able to automatically open toward the front of the school bus safety device used to protect the driver's field of vision when parking. The number of deaths according to Nanchang school bus accident statistics, in the past 15 years, the transverse control arm to install school bus involved only the device is not installed school bus involved in the deaths of $1 / 10$. Therefore, the use of the device is necessary for the protection of pupils safe.

Major accidents occur if the school bus vehicle collision, body roll, etc., because the body instantly extrusion shorted electrical lines and cause damage, etc., are very easy to cause a fire after the accident. In this case, the combustion performance interior materials will directly determine the length of time the passengers managed to escape, so its importance is self-evident. And students can not be in an emergency situation, the right to make judgments and to react quickly, the time needed to escape naturally longer than adults. Increase private primary school bus interior materials combustion characteristics requirements, is an important part of the development of a dedicated primary school bus safety standards.

Expect pupils within a particular environment such as a fire hazard, poor body resistance and self-help capabilities, should the school bus interior materials by combustion of oxygen index of requirements to achieve when a fire closed the school car interior materials can burn themselves out or as soon as possible Off the purpose, you can better ensure that students ride safe, so in school bus standards set forth in the index interior combustion oxygen index, which is prescribed in the automotive industry is the first set.

\section{Conclusions}

Based on domestic and school bus management system and security system were studied, on the basis of relevant standards and regulations and management systems study on the school bus, the main contents include vehicle structure, rollover protection, passenger seat, warning signs, safety belts centralized control devices, technical requirements and test methods for the driver's field of vision and interior materials, etc., to establish safety standards and performance standards and 
improve school bus. Introduced several new energy saving school bus, on school bus safety design system for planning.

\section{Acknowledgements}

This work was supported by Project of Jiangxi University of Technology [No. XJXT1413]

\section{References}

[1] Child Safety:School Bus Still Best. http://www.webmd.com/parenting/features/child safety-school-bus-still-best . 2012

[2] March C, Shim T. Integrated control of suspension and front steering to enhance vehicle hand ling[J]. Proceedings of the Institution of Mechanical Engineers, Part D: Journal of Automobile Engineering, 2007, 221(4): 377-391.

[3] Yu H, Güvenc L, Özgüner Ü. Heavy duty vehicle rollover detection and active roll control[J]. Vehicle System Dynamics, 2008, 46(6): 451-470.

[4] Canale M, Milanese M, Novara C. Semi-Active Suspension Control Using \&\# 8220; Fast\&\# 8221; Model-Predictive Techniques[J]. Control Systems Technology, IEEE Transactions on, 2006, 14(6): 1034-1046.

[5] Elbeheiry E M, Karnopp D C, ElAraby M E, et al. Advanced ground vehicle suspension systems-a classified bibliography[J]. Vehicle System Dynamics, 1995, 24(3): 231-258.

[6] Oleksowicz S A, Burnham K J, Southgate A, et al. Regenerative braking strategies, vehicle safety and stability control systems: critical use-case proposals[J]. Vehicle System Dynamics, 2013, 51(5): 684-699.

[7] Rauh J, Ammon D. System dynamics of electrified vehicles: some facts, thoughts, and challenges[J]. Vehicle System Dynamics, 2011, 49(7): 1005-1020.

[8] Kang X, Deng W. Vehicle-Trailer Handling Dynamics and Stability Control- an Engineering Review[R]. SAE Technical Paper, 2007.

[9] David S B, Bobrovsky B Z. Actively controlled vehicle suspension with energy regeneration capabilities[J]. Vehicle System Dynamics, 2011,49(6): 833-854.

[10]Krueger W R, Vaculin O, Spieck M. Evaluation of Active Damping for Reduction of Noise, Vibration and Motion of Ground Vehicles by Multibody Simulation[R]. DLR INST FOR AEROELASTICITY GOETTINGEN (GERMANY), 2004. 